\title{
Köy Seyirlik Oyunları Geleneği ve Çağdaş Tiyatronun Kesişim Noktasında Bir Oyun: Yunus Diye Göründüm ${ }^{1}$
}

\author{
Nurtaç ERGÜN ATBAŞI ${ }^{2}$
}

Başvuru Tarihi: 21.11.2021

Kabul Tarihi: 29.12 .2021

Makale Türü: Araştırma Makalesi

\section{Öz}

Yunus Emre Türk edebiyatının önde gelen zirve şahsiyetlerinden biridir. Onun eserleri ve yaşayışı dolayısıyla dil bilinci, inandiğı/savunduğu değerler düşünceleri/öğretileri kendi çağında olduğu gibi çağlar sonrasında da büyük bir etki sahası yaratmaktadır. Yunus Emre üzerine yürütülen akademik çalışmaların yanında sanat dünyasında ve özel olarak edebiyat ortaminda Yunus Emre'den etkilenen, ondan beslenen ve onu anarak yeni fikir ve biçim denemelerini ortaya çıkaran sanatçıların varlğ̆ından bahsetmek mümkündür. Bu bağlamda modern Türk edebiyatının birbirinden farklı dönemlerinde, farklı duyuş ve düşünüşe sahip farklı türlerde eserler kaleme alan sanatçları Yunus Emre'ye kimi zaman açık kimi zaman kapalı göndermelerde bulunarak kimi zaman da onun hayatın yeniden yazdıkları modern eserler kaleme almışlardır. Özellikle modern Türk tiyatrosunda Yunus Emre'yi konu alan çok sayıda eser bulunmaktadır. Nihat Asyalı da Yunus Diye Göründüm başlğ̆ını verdiği oyununda Yunus Emre'nin menkıbevi hayatından hareketle insanın anlam arayışını ve sahip olduğu direnme gücünü geleneksel unsurlarla çağdaş tiyatronun imkânlarmı birleştirerek işlemeyi tercih etmiştir. Bu çalışmada Yunus Emre'nin konu edildiği Yunus Diye Göründüm oyununun, geleneksel halk tiyatrosu içinde yer alan köy seyirlik oyunlarından ve ritüellerden ne tür izler taşıdığı üzerinde durulmuştur. Açık biçim-göstermeci tiyatro biçiminde yaratılan oyunda tiyatrosallığı sağlayan unsurlar; oyun içinde oyun kurgusu, dekor ve kostüm kullanımı, çatışma unsurları, şarkı ve şiirler aracılığıyla seyirciye iletilerin aktarılması ve dini, büyüsel ritüel nitelikte oyunlara dayanan köy seyirlik oyunlarının dua ya da dans gibi belli bir zaman ve durumda gerçekleşen ritüellerin de oyunda kullanılmasıdır. Bahsi geçen unsurlar göz önünde bulundurularak; Yunus Emre'nin yaşadığı devirden, düşünce dünyasından ve kültürel bir değer olan köy seyirlik oyunlarından da faydalanan Nihat Asyalinın kendi oyununda insana ait evrensel gerçekleri nasıl bir biçim ve içerik düzleminde işlediği tartışılmıştır.

Anahtar Kelimeler: Çağdaş Türk Tiyatrosu, Köy Seyirlik Oyunları, Ritüel, Nihat Asyal, Yunus Diye Göründüm

Atıf: Ergün Atbaşı, N. (2022). Köy seyirlik oyunları geleneği ve çağdaş tiyatronun kesişim noktasında bir oyun: Yunus Diye Göründüm. Anadolu Üniversitesi Sosyal Bilimler Dergisi, 22(Özel Sayı), 271-286.

\footnotetext{
${ }^{1}$ Bu çalışma etik kurul izin belgesi gerektirmemektedir.

${ }^{2}$ Hacettepe Üniversitesi Edebiyat Fakültesi Çağdaş Türk Lehçeleri ve Edebiyatları Bölümü, nurtac@hacettepe.edu.tr, ORCID: 0000-0003-3927-5194
} 


\title{
A Play at the Intersection of Dramatic Village Plays and Contemporary Theatre: Yunus Diye Göründüm
}

\author{
Nurtaç ERGÜN ATBAŞI ${ }^{3}$
}

Submitted by: 21.11 .2021

Accepted by: 29.12 .2021

Article Type: Research Article

\begin{abstract}
Yunus Emre is one of the leading figures of Turkish culture, language and literature. Due to his works and life experience, his awareness of the language, the values he holds and stands by, and his thoughts and teachings have a great impact in his own age, as well as in the ages after. In addition to the academic studies conducted on Yunus Emre, it is possible to mention the existence of artists who were influenced by Yunus Emre in the art world and especially in the literary environment, that got inspired by him and brought out new ideas and form attempts by taking him as a reference. In this context, in different periods of modern Turkish literature, artists that had varied perception and thought, and wrote in diverse genres have conceived modern works, sometimes as openly or covertly referencing him and sometimes rewriting his life. Especially in modern Turkish theatre there are a lot of works on the subject of Yunus Emre. For an example of this, Nihat Asyal also chose to process the mankind's search for meaning and its inherent power of tenacity in his play based on Yunus Emre's life of legend and titled Yunus Diye Göründüm, by combining traditional elements with the possibilities of modern theatre. This study will focus on the impressions of theatrical village plays and rituals that come within traditional public theatre on the work based on Yunus Emre titled Yunus Diye Göründüm. The elements that implement theatricality in this play formed on the basis of open formed exhibition drama are nested fiction, usage of decor and costumes, conflict, transmission of messages by song and poetry, and the usage of time and condition sensitive rituals like prayer or dance that come from theatrical village plays, which are themselves sourced on rituals of the religious and magical in nature. Considering the mentioned elements, the form and content basis of this play that handles universal realities of mankind by Nihat Asyal, who utilizes the age in which Yunus Emre lived, his world of thought and theatrical village plays that are a cultural value, is discussed.
\end{abstract}

Keywords: Contemporary Turkish Theater, Nihat Asyal, Yunus Diye Göründüm, Dramatic Village Plays, Ritual

\footnotetext{
3 Hacettepe University Faculty of Arts Department of Modern Turkic Languages and Literatures, nurtac@hacettepe.edu.tr, ORCID: 0000-00033927-5194
} 


\section{Giriş}

Yunus Emre Türk edebiyatının önde gelen ve çağlar sonrasında da değerini yitirmeden anılmaya devam eden zirve şahsiyetlerinden biridir. Kesin bir tarih belirlenememekle beraber XIII. yüzyılın ikinci yarısıyla XIV. yüzyılın ilk yarısında yaşadığı kabul edilen Yunus Emre, hem içinde farklı öğretileri barındıran menkıbevi hayatında hem de Risâletü’n-Nushiyye ve Dîvân olmak üzere bilinen iki eserindeki şiirlerinde "farklılıkları anlayışla karşılamayı, bütünleşmeyi, hoş görmeyi, sevmeyi öğretmeye” (Günay 1999: 37) çalışan bir şair, bir bilge, bir derviş olarak kendi yaşadığı dönemin ötesinde de varlığını çeşitli biçimlerde sürdürmektedir.

Yunus Emre; felsefesi, eserlerindeki dil kullanımı ve Türkçe sevgisi dolayısıyla her devirde hem araştırmacılar hem de sanatçlar tarafından ilgiyle ve merakla tekrar tekrar ele alınmıştır. Yunus Emre ile ilgili çalışmalar Fuat Köprülü'nün 1913'te Türk Yurdu'nda sanatçı ile ilgili ilk makaleyi yayımlamasının ardından günümüze değin artarak devam etmiştir. Bu süreçte hayatı, eserleri, sanatçı kişiliği, düşünce dünyası üzerine araştırmalar yürütülen Yunus Emre hakkında yapılan yorumlar birbirinden farklılık göstermiş ve her bir farklı yorum tartışmaları da beraberinde getirmiştir. Yunus Emre’nin düşünce ve sanat dünyasının yorumlanması sürecinde ortaya çıkan farklılıklar şüphesiz onun kendinden sonraki çağlarda, modern çağın insanına yol gösterebilecek zenginliğe sahip oluşuna dayanmaktadır. Yunus Emre'nin adının sadece araştırmalar dolayısıyla değil sanatsal üretimlerle de anıldığı ve yaşatıldığı gerçeği -sinemada ve plastik sanatlarda da yer alsa da- kendisini en çok edebi metinler aracıllğıyla gösterir. ${ }^{4}$ Yazarlar ve şairler Yunus Emre'nin hayatını, öğretilerini yarattıkları şiir, roman, tiyatro gibi farklı türlerde kaleme aldıkları metinlere konu etmişlerdir. Modern Türk edebiyatı tarihi incelendiğinde tespit edilen çok sayıdaki eserde, Yunus Emre’nin bazen açık bazen örtük biçimde izlerine rastlamak mümkündür. Türk şiirinin çok kuvvetli bir sesi olarak Yunus Emre, kendinden sonraki şairlerin şiir dilini ve imaj dünyasını etkilemiş, onun diline öykünen, düşüncelerine yaslanan şiirler kaleme alınmıştır. Yunus Emre'yi konu alan roman, hikâye ve tiyatrolarda ise daha çok onun menkıbevi hayatının işlendiği, düşünce dünyasına göndermelerde bulunulduğu söylenebilir.

Tüm dünyada olduğu gibi halk edebiyatının destanlarla, halk hikayeleriyle, masallarla, efsanelerle, halk şairleriyle ve daha pek çok unsurla Türk edebiyatında da modern metinlere kaynaklık ettiği görülür. Bahsi geçen modern metinlerin içinde tiyatro ayrıcalıklı türler arasındadır; çünkü tiyatronun halk edebiyatından ve halk edebiyatı ürünlerinden kaynak olarak faydalanması ${ }^{5}$ sahneye koyma ve içerik açısından olmak üzere iki yönlüdür. Modern Türk tiyatrosu, geleneksel Türk tiyatrosundan teknik olarak faydalanmasının yanında bir de üretilen modern tiyatro metinlerinde; Türk tarihinin, halk edebiyatının ve bazı zirve şahsiyetlerin hayatlarının ve eserlerinin işlenişi söz konusudur (Tan 2001/4:121). Tiyatro yazarlarının Yunus Emre'yi konu etmiş olmaları da halk edebiyatını kaynak olarak kullandıklarının somut göstergelerinden biridir. Yunus Emre sanatçılığının, eserlerinin, felsefesinin ve menkıbevi hayatının içinde barındırdığı zengin anlam dünyası ile yazarlar tarafından tiyatro eserlerine sıklıkla konu edilmiştir. ${ }^{6}$

Yunus Emre'yi odak noktasında tutan tiyatro eserlerinden biri de Nihat Asyalı'nın Yunus Diye Göründüm oyunudur. Yunus Diye Göründüm hem içeriği hem de yapısal özellikleri dolayısıyla modern bir metin olarak geleneksel Türk tiyatrosundan taşıdığı izlerle geleneğin dönüşerek sürdürülmesi noktasında dikkati çeken özgün bir eserdir. Asyalı'nın Yunus Emre'nin hayatından hareketle kurguladığı eserinde Yunus Emre'nin beraberinde getirdiği anlam dünyasını, biçim ve içerik yönünden bir taraftan epik tiyatronun olanaklarından diğer taraftan köylü tiyatrosu geleneğinden faydalanarak desteklemesinin Yunus Diye Göründüm'ün özgün değerini açığa çıkaracağı düşünülmektedir.

\footnotetext{
4 Ayrıntılı bilgi için bkz. Ayvazoğlu 2014.

5 Türk tiyatrosunun kaynakları hakkında ayrıntılı için bkz. Töre 2009.

6 Türk tiyatrosunda Yunus Emre konulu eserler üzerine yapılan çalışmalar için bkz. Akyüz, 2017; Aşkın, 2011; Çınar, 2020; Şengül, 2020; Tan, 2001; Ulutaş 2018.
} 


\section{Nihat Asyalı'nın Köylü Tiyatrosu Geleneğinden Beslenen Modern Kurgusu}

Nihat Asyalı, modern Türk tiyatrosuna kazandırdığı uyarlamaları ve telif eserlerinin yanında Ankara Üniversitesi Tiyatrosu, Sinema Tiyatro Derneği, Tiyatro Sevenler Gençlik Cemiyeti, Ankara Deneme Sahnesi gibi topluluklarda hem oyunculuk hem yönetmenlik yaparak tiyatro ile çok yönlü bir bağ kurar. Nihat Asyalı'nın tiyatro uyarlamaları (Boccaccio'nun Decameron'daki bir öyküsünden) Dirilen Adam, (Yaşar Kemal'in Yer Demir Gök Bakır romanından) Uzundere, (F.Gladkov'un romanından) Çimento, (I. Gonçarov'un Oblomov romanından) Oblomov, (Fahir Aksoy'un anılarına dayanan) Kürdün Meyhanesi, (Nazım Hikmet'in Memleketimden Insan Manzaraları'ndan) Nazım Hikmet'in İnsan Manzaralarından On Bir Tablo adlarını taşır (Asyali, 2010, s.199).

Türk ve Dünya edebiyatlarından tiyatroya uyarladı̆̆ eserlerinin yanında Ateşle Oynayan, Yanar Elleri, Devlet Kuşu ve Rab Şeytan'a Dedi ki isimli telif oyunları ile de Türk tiyatro edebiyatı tarihinde yer alan Nihat Asyalı, kaleme aldığı ve 1980'li yıllardan itibaren sahneye konan bir diğer telif eseri Yunus Diye Göründüm’ü, Yunus Emre'nin hayatının etrafında kurgular. Modern çağda vazgeçilmez bir değer olarak Yunus Emre adının sanat eserlerinde yaşatılmasının örneği olan bu oyunun içerdiği özü, Asyalı oyununa yazdığı önsözde okuru ile şu cümlelerle paylaşır:

Gerçek insanın, Yunus Emre’nin kişiliğinde, insanın; Anadolu insanının türlü kıyımlar, kırımlar, yıkımlar karşısında direnişi sergilenmiştir. Bu direniş gücünü nereden alıyor insan? Soruyu yanıtlarken bakış açısı az çok belli olsa da dar bir açıdan bakılmadığı görülecektir. Oyundaki düşünce değişik yorumlara açık bırakılmıştır. Yukardaki soruyu yinelersek; “Direniş gücünü nereden alıyor insan?" diye yeniden sorarsak yanıtı şudur bu sorunun: İnsan direnme gücünü kendinden alır, direnme gücü insandadır.

Yunus'un öğretmeni de Yunus’a bunu öğretti:

Hararet nardadır sacda değildir.

Keramet hırkada taçta değildir.

Her ne arar isen kendinde ara

Kudüs'te, Mekke'de Hac'da değildir. (Asyalı, 2010, s.7)

Nihat Asyalı'nın oyununu kurgularken köylü tiyatrosu/köy seyirlik oyunları ve onun altında kümelenen ritüel oyunlar ile Bertolt Brecht'in -yine doğu tiyatrosunu kaynak alarak ürettiği- epik tiyatro anlayışı olmak üzere geleneksel ve modern iki farklı kaynaktan beslendiğini söylemek mümkündür. İki kaynağın hem birbirinden farklı yanlarını hem de kesiştikleri noktayı kullanarak özgün bir metin yaratan Asyalı, böylece Yunus Emre'nin kişiliğinde ele aldığı insanın, kendini ve gerçeği arayış serüvenini farklı boyutlarda işleme imkanına kavuşmuş olur. Oyunun, yirminci yüzyıl tiyatrosunu kuvvetli bir biçimde etkilemiş olan epik tiyatro ile bağı, epik tiyatronun kullandığı teknik ve anlayış bağlamında düşünüldüğünde anlamlı veriler sunmaktadır. Böylece en somut göstergelerden biri olarak, oyunun anlamsal katmanında iktidar ve halk arasındaki ezen-ezilen ilişkisini "toplumsal ve politik konuları ele alan, seyircinin bu konular üzerinde düşünüp fikir yürütmesini; tartışmasını, yargıya varmasını sağlayan, bilgilendirici, tezli, taraflı eleştirel-gerçekçi ve diyalektik bir tiyatro anlayışı olan" (Doğan, 2009, s.411) epik tiyatronun eleştirel tutumuyla bağdaştırmanın mümkün olduğu söylenebilir.

Yunus Diye Göründüm'ü yorumlama aşamasında ayrı ayrı veriler sunan köylü tiyatrosu/köy seyirlik oyunları ile epik tiyatro'nun kesişim noktasını ise açık biçim oluşturmaktadır. Açık biçim tiyatroda eylemdeki yer ve zaman çokluğu yani eylemin düz bir çizgiyi izlememesi, çeşitlilik ve karşıtlık içinde gelişmesi; olayların kendi içinde süreklilikten yoksunluğu, bitişe doğru ilerlememesi; oyunun sahnelerinin tek başına varoluşu, ana konunun her sahnede başka bir konumda var olmasıyla tek tek her sahnenin bir özelliğinin ana konunun özelliklerinden biri oluşu; oyunun ekseni olmayan oyun kahramanının davranışlarını ise dış dünyanın belirlemesi; oyun kişilerinin yer-zaman-eylem bölümlenmesi ve çeşitliliği içinde yer alması; oyun dilinin de çeşitlilik ve çokluk göstermesi; oyun içinde şiir, müzik, dans kullanımı; izleyiciye doğrudan seslenme ya da 
şarkı yoluyla oyunla ilgili bilgi verilmesi, yorum yapılması; kostümün, ışığın ve dekorun izleyiciye bilgi vermek ve yanılsamayı yıkmak için kullanılması söz konusudur (Çalışlar, 2004, s.5-6). Epik tiyatronun olaylar dizisinin anlatımını öncelemesi, yabancılaştırma tekniği ile seyircinin oyunla özdeşleşmesini engelleyerek onu, seyrettiği oyun karşısında düşünmeye ve yargıya varmaya sevk etmesi sahnelenen oyunun seyirci, oyun ve oyuncu arasındaki etkileşiminin önemini gösterir. Köy seyirlik oyunlarında da benzer biçimde seyirci, oyun ve oyuncunun etkileşimi dolayısıyla tiyatrosallık söz konusudur.

Köy seyirlik oyunları kaynağı itibariyle, toplu katılım ve toplu kutlama-kutsama’nın esas alındığı oyunlardan oluştuğu için, köylünün yaşamının vazgeçilmez bir parçasıdır. Bu yüzden bu tür oyunları, konvansiyonel tiyatrodan ayıran temel özelliği, (...) Açık Biçim-Göstermeci Tiyatro tarzında olması ve bu tarzın en ayırıcı özelliği olan oyuncu-oyun-seyirci organik bağı, oyunsuluk-tiyatrosallık, tören ya da eğlence atmosferinin getirdiği oyuncu ve seyirci arasındaki alışveriştir (Tekerek, 2008, s.138)

Anadolu coğrafyasında köylünün yılın belirli günlerinde oynadığı köy seyirlik oyunları, kökleri tarihin çok uzak bir geçmişinde yer alan atalara tapınma, bolluk, canlandırıcılık gibi işlevsel dini törenlere yaslanan bir tiyatro geleneği olarak özünde ritüelleri barındırmaktadır. Anadolu’nun Türklerden önce pek çok uygarlığa ev sahipliği yaptığı göz önünde bulundurulduğunda ritüel oyunların yok olmadan fakat birtakım dönüşümler geçirerek devamlılı̆̆ının sağlandığı gerçeğinin en somut ve son göstergesi Anadolu köylüsünün tüm canlılığ ve çeşitliliği ile bu oyunları günümüze değin yaşatabilmiş olmasıdır (And, 1985, s.43). Köylünün oynadığ1 ritüel oyunlara bakıldığında baharın gelişi, hasat sonrası, hayvanların üremesi, dini bayramlar gibi sebeplerle düzenli olarak oynanan oyunların yanı sıra kuraklık, hastalık tedavisi gibi beklenmedik olaylar karşısında da oyunların oynandığı görülür (Korkmaz, 2019, s.64). Ritüel oyunların zamanla dünyevi oyunlara evrilmiş olması yapısal bakımdan büyük bir değişimi beraberinde getirmemiştir. Genel hatlarıyla köy seyirlik oyunlarının yapısı için bir değerlendirmede bulunulduğunda ise değinilmesi gereken bazı noktalar vardır: açık biçim (göstermeci) tiyatro olarak köyün açı alanlarında köylüler tarafından köylülerin seyretmesi için oynanır; oyuncuların hiçbiri profesyonel değildir. Seyirci ve oyuncu iç içe geçmiştir; bir kişi birden fazla rolü üstelenebilir. Kılık değiştirme bu bağlamda çok önemlidir. Seyircinin içinden çıkan oyuncu, rolünü tamamladığında tekrar seyircinin arasına döner. Seyirci bir oyunun içinde olduğunun daima bilincindedir. Oyunda bir anlatıcının bir yöneticinin varlığı önemli bir yer tutar. Dans ve müzik kullanımının da oyunun yapısında önemli bir yeri vardır. Dekorun ve kostümün basit eşyalarla sağlandığı seyirlik oyunlarda birbirini tekrar eden çatışma unsuruna dayanan belli başlı motiflere rastlanır.

Köy seyirlik oyunlarının kaynağında inanç, gelenek, doğayla iç içe yaşamış Anadolu insanının doğayı, evreni, insanı yorumladığı ve bütün bu değerler içinde kendini de konumlandırdığı törensel etkinlikler vardır. Anadolu köylüsünün Totemizm, Şamanizm, Batınilik, Alevilik ve Bektaşilik gibi inançlarıyla oyun çıartma geleneğini kaynaştırdığı yüzyıllardır titizlikle koruyarak günümüze dek getirdiği bu oyunların çağımız tiyatral arayışlarıyla da kesişen özellikleri vardır. Bu oyunlar büyüsel ve törensel kökenli olduğu için köylünün doğayla ilişkisini, ondan beklentilerini, umutlarını, dileklerini içeren ve simgesel anlamları olan motiflerle yüklüdür ve açık biçim-göstermeci tiyatronun pek çok özelliğine sahiptir. Soyut sanatın en önemli uğraklarından fantaziyi, imgelemi, olağanüstüyü, masalımsı olanı, simgesel olanı da içinde barındırmaktadır. $\mathrm{Bu}$ simgesel motifler ve göstermeci ögeler eylem dizgelerinden kişileştirmeye, kişileştirmeden oyun düzenine, oyun alanına, giysilere, danslara, türkülere kadar her alana yansır (Tekerek, 2008, s.105).

Metin And (1983), Anadolu Türklerinin kültürünün dolayısıyla dramatik sanatının yer, soy, İmparatorluk, İslam ve Batılılaşma'dan oluşan beş etken sonucunda meydana geldiğini savunurken yer ile Anadolu'da yaşayan eski uygarlıkların Türk kültürünün oluşmasındaki büyük rolünü, soy unsuru ile de Türklerin eski yurdu Orta Asya'nın ve Şaman inançlarının izlerine Anadolu Türklerinin kültüründe geniş ölçüde rastlanmasını kastetmiş (s.7) ve köylü tiyatrosunun oluşumunda bu iki unsurun etkilerini pek çok çalışmasında irdelemiştir. Türk tiyatrosunun kaynaklarının zenginliği düşünüldügünde Yunus Diye Göründüm oyununun modern bir tiyatro metni olmasının yanında köy seyirlik oyunlarının yapısal ve anlamsal bakımdan izlerini 
taşımaktadır. Tiyatro metninde yer alan açıklamalar metnin taşıdığı geleneksel izlerin ilk işareti konumundadır. Sahne, giysi, ışık, dans ve müzik bilgilerine ek olarak rol dağılımında bazı rollerin aynı kişi tarafından oynanacağı bilgileri köy seyirlik oyunlarının yapısına bir gönderme olarak okunabilir. Asyalı, Yunus Diye Göründüm'ü, köy seyirlik oyunlarının yapısal özelliklerinin tamamını birebir alarak değil belli motifleri ve özellikleri kullanmak suretiyle -örneğin oyununun içine Anadolu köylüsünün ritüel oyunlarını yerleştirerek- kurgulamıştır.

\section{Olay Çizgisi: Tarihi Kimler Yazlyor?}

Nihat Asyalı'nın Direniş Üçlemesìnde Ateşle Oynayan ve Rab Şeytana Dedi ki'nin ardından gelen üçüncü oyunu Yunus Diye Göründüm, ön ve son oyunlara sahip iki perde, -her birine ayrı başlık verilmiş- on yedi sahneden oluşan müzikli bir oyundur. Eserde Yunus Emre'nin menkıbevi hayatından hareketle insanın tarihi gerçeklerin içindeki konumunun yanında hayatındaki anlam arayışı ve arayışını kendine doğru değil dışarıda sürdürmesi konu edilir.

Eserin birinci perdesi ön oyun ile başlar. Ön oyunda kuşlar ve onların öncüsü Hüthüt kuşunun dans ederek söyledikleri şarkıdan kuş milletinin kendilerine bir sultan aramak üzere yola çıkacakları öğrenilir. Kuşların dansının ardından sahneye oyunun anlatıcıları olarak gelen ve oyun boyunca da bu rolü üstlenecek Ozan ve Sunucu, tarihi kimlerin ve neyin oluşturduğu konusunda münakaşa ederler. Sunucu, tarihi sultanların, komutanların, vezirlerin, kahramanların yarattığını iddia ederken Ozan ise gerçek tarihi görebilmek için yüzlerin halka doğru dönülmesi gerektiğini söyler ve oyun başlar.

Anadolu'da kuraklık yaşanan bir köyde köylüler çaresizce ne yapacaklarını bilmeden beklemektedirler. Onların arasında kuraklık yüzünden Tanrı'ya isyan eden Yunus da yer almaktadır. Köyün bilge kadını İbiş Ana ise güvercin dansı yaparak toprağı çapalar. Yunus da İbiş Ana'dan duyduğu "Adam olan ölmez, korkma. Yeter ki adam olasın” sözlerini tekrar ederek toprağı çapalamaya girişir. Köylünün anlam veremediği hareketler sergileyen İbiş Ana, bu kıtlığın içinde umutla Hacı Bektaş-1 Veli’nin Tanrı’nın onlara gönderdiği erenlerden bir er kişi olduğunu anlatır. Yunus, Hacı Bektaş-1 Veli'nin yanına gitmek için yola çıkar ve yolda ona sunmak üzere alıç toplar. Alıçları sunduğu Hacı Bektaş-1 Veli, Yunus'un kıtlık girmiş köyündeki köylüler için buğday istediğini öğrenince, buğday yerine soluk vermeyi teklif eder. Yunus buğdaya çok muhtaç olduklarını belirterek soluk yerine buğdayı seçer. Köyüne dönerken Hüthüt kuşu ve diğer kuşlarla karşılaşır. Yunus onların farkında değilse de Hüthüt, kuşların ulaşmak istediği sultanın varlığı ve ona ulaşmak için ne yapmak gerektiği konusunda yaşadığı kararsızlığı yine Yunus'un kendi kendine konuşurken sarf ettiği sözlerle aşar. Çünkü o sırada Yunus da Hacı Bektaş-1 Veli’nin kendisine teklif ettiği soluğu anlamlandırmaya çalışmaktadır. Yunus'un aydınlanma anında ağzından dökülen "Bir bilsem de ossaat ÖLSEM!" sözü Hüthüt’e de "Ölmek gerekse ölmeli, bilmek uğruna ölmeli” sözlerini söyleterek kuşların Kaf Dağı’na doğru yola çıkmalarına sebep olur. Dergâha geri dönüp buğday değil soluk istediğini söyleyen Yunus'a Hacı Bektaş-1 Veli bunun mümkün olmadığını, istediği kilidin anahtarının Taptuk Emre’ye verildiğini ve emeğine değeceğini düşünüyorsa ona gitmesi gerektiğini yoksa buğdayı alıp gidebileceğini söyler. Yunus buğday çuvalını bırakıp Taptuk Emre’ye gitmek üzere yola çıkar.

"Sanki İnsan Devlet İçin” başlığını taşıyan beşinci sahnede tekrar ortaya çıkan Ozan ve Sunucu birbirlerini ikna çalışmalarını sürdürürler. Ozan'ın asıl tarih dediği -halkın durumunu gözler önüne seren- ilk dört sahnede anlatılanları Sunucu, masal olarak nitelendirir ve gerçeğin kitaplarda yazılı olduğunu savunur. Ozan'ın tarihi olayları anlatmasıyla toprak ve iktidar uğruna verilen savaşların sonunda hangi sultan, hangi komutan kazanırsa kazansın kaybedenin daima insan, daima halk olduğu gerçeğini vurgulaması Sunucu'nun fikrini değiştirmez. Sunucu, şan ve şeref için ölmenin tarihe şan verdiğini savunmaya devam eder. Sahnedeki vitrinlerin içinde yer alan donuk figürleri canlandıracak oyuncuların sahneye çıkmasıyla Sultan Rükneddin Kılıç Arslan ile onun veziri Muineddin Pervane konuşmaya başlar. Konuştukları konu Rükneddin Kılıç Arslan 
ve İzzeddin Keykavus arasındaki taht kavgası ve Pervane'nin bu konudaki sinsi planlarıdır. Pervane'nin en büyük planı Türkmen'i Türkmen'e kırdırmaktır. Halk, hiçbir çıkarı olmamasına rağmen bu savaşın yıkımını en çok yaşayan olur. Sultanının ve vezirinin planları doğrultusunda köylülerin arasından sultan için savaşacak asker toplanmak istenir. Bunun için Yunus'un köyüne giden Seyfullah başta İbiş Ana olmak üzere köylülerin tepkisiyle karşılaşır. Köylüler sultanın ordusunda savaşmak için içlerinden kimsenin asker olmasını istemese de Seyfullah kılıç oyunu ile Hüseyin’i kandırarak onu Sultan’ın ordusuna asker olarak katmayı başarır.

Yunus, Taptuk Emre'yi bulmaya çalışırken kuşların sultanını aramak üzere Kaf Dağı'na doğru yol alan Hüthüt ve diğer kuşlarla yolu tekrar kesişir. Hüthüt, arayış yolunda yorulan kuşlara da Yunus’a da bu yolda can vermek gerektiğini, sabır göstermek gerektiğini hatırlatır. Hüthüt, Yunus'a; kuşlar da Tapu Erenleri’ne ve Bacılar’a dönüşür. Böylece Taptuk Emre’nin dergahına varmış olur. Yunus'un karşısına çıkan ilk kişi Taptuk Emre’nin eşi Anabacı olur ve onu Taptuk Emre'nin yanına götürür. Yunus'un, Taptuk Emre'den soluk istemesi üzerine derviş, Yunus'a Hacı Bektaş-1 Veli'nin onu neden kendisine yolladığını sormasının yanında Yunus'un kendisini tanıtması ve özünün farkına varması için de sorular sorar. Yunus, Taptuk Emre’nin dergahına kabul edilse de karşı karşıya kaldığı sorgulamanın neticesinde kendini bulmak için oradan ayrılır. Yunus'un yolculuğu gibi, yorgun kuşların da Kaf Dağı’na yolculuğu devam etmektedir. "Sultan Gider, Sultan Gelir... Dönem Pervane Dönemi” başlığını taşıyan dokuzuncu sahnede Ozan ve Sunucu'nun sahnede belirmesiyle tekrar asıl tarihin ne olduğu tartışması dile gelirken kitaplarda yazılan tarih bilgisinin anlatımına geri dönülür. Pervane, Komutan ve Sultan Rükneddin Kılıç Arslan ile görüşmesinin ardından Sultan Rükneddin’in Moğol Han'ı tarafından öldürülmesi, tahta da üç yaşındaki Gıyaseddin Sultan'ın geçişi ve kontrolün Pervane’nin eline geçtiği Sunucu ve Ozan tarafından anlatılır.

Köylülerin hasat-önü şenliğine İbiş Ana dahil olmak istemez çünkü tarladan topladıkları ürünlere, Sultan'ın ordusuna gönderilecek askerlere yemek olmak üzere Bey tarafından el konulacağını bilir. Nitekim şenlik devam ederken Beytullah gelir ve Bey’in payını almak istediğini söyler. İbiş Ana mahsulü vermemek için Beytullah ile mücadele ederken çekirge sürüsü tarlayı talan eder. Tarlada hiç ürün kalmamıştır ama İbiş Ana buna rağmen ayağa kalkar ve güvercin türküsü müziğine eşlik ederek dans etmeye başlar. Yunus'un da gizlice bir köşede izlediği dansa tüm köylüler dahil olur. Umutla ve sevinçle dansa eden köylüyü gören Beytullah'un “Bu köylü öldü-dirildi, ya ben n’olacam şimdi?” sözleriyle birinci perde sona erer.

Oyunun ikinci perdesi Ozan ve Sunucu'nun perde önü konuşmalarıyla başlar ve Yunus'un Taptuk Emre'nin dergahına dönüşüyle devam eder. Çilehaneye giren Yunus dile gelir ve şiirler söylemeye başlar. Çilehaneden çıkıp Taptuk'un tapusundaki günlük çalışma düzenine dahil olan Yunus, odun kesmektedir. Odun keserken de daima bir ezginin eşlik ettiği dizeler dökülür dilinden. Bunları dinleyen Taptuk Emre, odundan döndüğünde Yunus'u "Hoş gelmişsin Yunus Emre" diyerek karşılar ve ona kopuzu uzatarak kilidinin açıldığı haberini verir. Simurg’u arayan kuşlar ve Hüthüt ise Kaf Dağı'na ulaşmışlardır. Kuşlar, Hüthüt'ün Simurg’u yanlarına getirmesini beklemektedir. Yunus'un köyünde ise bir Çerçi tarafından Yunus'un dizeleri dilden dile dolaşmaya başlamıştır. Çerçi her köyün onu sahiplendiğini söylese de İbiş Ana ve köylüler Yunus'un nereye ait olduğunu bilirler. İbiş Ana, Yunus'un sözlerinden dolayı başına bir iş gelmesinden korkup başta Yunus'u anmak istemese de sonra onun sözleriyle aydınlanan köylünün Yunus'un dizelerini sık sık tekrarlamasını ister. "Sanki Devlet Bir Oyuncak" başliklı on dördüncü sahnede Ozan ile Sunucu ve onların zaman zaman döndükleri tarih kitabının asli kahramanları Pervane ile Komutan kendini gösterir. Tüm planlarına rağmen Karamanoğlu Mehemmed'in başarısı, Konya'yı ele geçirmesi, Türkçeye hak ettiği yeri vermesini Pervane içine sindiremez ve yeni bir tedbir düşünerek Anadolu'ya Moğol Han'ını davet eder. Komutanın Pervane'ye, Yunus isimli Türkmen bir dervişin halkı kışkırttığını ve bu yüzden tehlikeli olduğu bilgisini vermesinin ardından vezir, Yunus'un yaşadığı yer olan Taptuk Emre’nin dergâhına denetçi yollar. Dergâha Yunus'u aramaya gelen denetçilere oradaki her erenin Yunus olduğu söylenir ve Yunus Emre ele verilmez. Tapu erenlerin ve bacıların kılığı ile karışık haldeki kuşlar Simurg’un kendileri olduğu gerçeğini öğrenirler. Kuşların bulunduğu yere 
Denetçiler gelip Hüthüt'e Yunus'u görüp görmediğini sorarlar ve Hüthüt de oradaki tüm kuşların Yunus olduğunu söyler. Kuşlar ardından, köylülere dönüşürler. Oyunun sonunda Ozan ve Sunucu Pervane’nin yok oluşunu anlatırlar. Moğollarla iş birliği yapan vezir Pervane’nin ve Komutanın Moğollar tarafından öldürülüşü, Moğol saldırısının halkı mahvetmesi Ozan ve Sunucu tarafından üzüntüyle karşılanır ve bu duruma ağıt yakarlar. "Eğer İnsan İsen Ölmezsin Korkma” başlı̆̆ını taşıyan “Son Oyun”da ise oyunun iletileri ile örülü Yunus Emre’nin şiirleri, kendi sesinden duyulurken eser son bulur.

\title{
Yunus Diye Göründüm'ün Köy Seyirlik Oyunlarından Taşıdığı İzler
}

Farklı inanç sistemlerindeki köylünün doğanın içindeki yaşamında belli zaman dilimlerinde ve belli sebeplerle gerçekleştirdiği büyülü, kutsal törenlerin kökenini oluşturduğu köy seyirlik oyunları "bir başkasını canlandırma-taklit-yansılama ve dolayısıyla düş gücü-imgelem'in kullanılması ve bu taklidin çeşitli anlatım araçları yardımıyla söz ve eyleme dönüşmesi ve bu sürecin seyreden bir toplulukla paylaşılması" anlamına gelirken dramatik köylü oyunları olarak da anılmaktadır (Tekerek, 2008, s. 35-36). Ahmet Kutsi Tecer (1940) Şükrü Elçin (1991), Metin And (1985; 2012), Nurhan Karadağ (1978), Nurhan Tekerek (2008), Korkmaz (2019) çalışmalarında Anadolu topraklarının bir ürünü olarak köy seyirlik oyunlarının kaynaklarına değindikleri gibi kendi içinde gösterdiği değişimleri göz önünde bulundurur ve köy seyirlik oyunlarını içeriklerine, oynanma amaçlarına, işlevlerine göre de tasnif ederler, zaman zaman farklı bakış açıları sunarlar. ${ }^{7}$ Hangi inanç sisteminin içinde olursa olsun insanlar tarafından gerçekleştirilen ritüellerin ve ibadetlerin yapısı, kullanılan motifler kendini köylülerin oyunlarında göstermektedir. Başlangıçta büyü kökenli, dini ve törensel oyunların zamanla özel günlerde eğlence amaçlı oynanan dünyevi oyunlara dönüşmesi köy seyirlik oyunlarının dinamik yapısını göstermektedir. Dönüşüm sürecinde köy seyirlik oyunlarının çağdaş nitelikli oyunlara da evrildiği ve varlığını farklı bir şekilde çağdaş oyunlarda devam ettirdiği görülür.

Çağdaş oyun yazarlarının beslendiği en verimli kaynaklardan biri olarak köylü tiyatrosunun ya da bir diğer adıyla köy seyirlik oyunlarının ${ }^{8}$ değişim gösteren varlığı "bir ulusun kültürünün temel unsurlarını canlı tutmanin yolu olarak onların sürekli olarak başka dönemlerde güncellenmelerine bağlı” (Aktulum, 2013, s.9) oluşu noktasında büyük bir anlam kazanmaktadır. Değișerek ve dönüşerek varlığını çağdaş oyunlarda sürdüren devingen özellikteki köy seyirlik oyunları böylelikle kültür unsuru olarak durağanlık, basmakalıplık ve klişeleşme tehlikesini aşmıştır.

\begin{abstract}
Dramatik metin olarak yazılan çağdaş nitelikli köy seyirlik oyunları, köy seyirlik oyunlarının öz ve biçim yapısını yansıtan, estetik bir bakış açısıyla çağdaş oyun teknikleri ile yazılmış oyunlardır. Bu oyunlar; bir yönetmen tarafından sahnelenen ve profesyonel oyuncuların oynadığı ve biletli seyirci tarafından tiyatro salonunda veya oynamaya müsait başka bir mekânda, izlenmek üzere yazılır. Çağdaş nitelikli köy seyirlik oyunları köylerde oynanan oyunlardan farklı olarak dram sanatı teknikleri ile toplumsal bir konu ve tema çerçevesinde, neden sonuç bağ gözetilerek, giriş gelişme düzleminde, tip ve karakter boyutlu kişilerle kurgulanarak dramatik nitelikli bir metin yapısına sahiptir. Açık biçim göstermeci tiyatronun yapısal özelliklerini yansıtan; oyun içinde oyun, soyutlama estetiği ve yabancılaştırma bu oyunların temelini oluşturmaktadır (Tangal, 2020, s.96).
\end{abstract}

Nihat Asya'nın seksenli yıllarda yazmış olduğu Yunus Diye Göründüm de açık biçim göstermeci tiyatro türünde yazılmış ve köy seyirlik oyunlarından izler taşıyan bir oyundur. Yazar oyununda, insanoğlunun kendini arayış yolculuğunu ve kendi ifadesiyle "baskılara karşı direniş serüvenini” birbirleriyle bağlantılı da olsa ayrı gruplar ve koşullar etrafında anlatır. Oyunda Yunus Emre, bir gösterge olarak kullanılmasına karşın

\footnotetext{
7 Köy Seyirlik Oyunları hakkında yapılan son çalışmalardan biri olan Köy Seyirlik Oyunlarında İnsan, Doğa ve Topluluk İlişkisi başlıklı kitabında Metin Basat (2017) bu oyunları "insanın kişisel alanları, doğayla kurduğu ilişki ve toplumla bütünleştiği sosyal alanlar olarak üç temel fikir üzerinden" inceler (s.6).

8 Köy seyirlik oyunlarının çağdaş metinlerdeki yansımaları üzerine çalışmalar için bkz. Tekerek 2008; Tangal 2020. Sadece çağdaş tiyatroda değil farklı biçimlerde de kendini yenilemeye devam eden köy seyirlik oyunlarının gösteri danslarına dönüştürülmesini konu alan örnek çalışma için bkz. Özdinçer, 2011.
} 
anlatılanların odağında yer almaz. Tarihi gerçeklerin hangi kaynağa dayandığını sorgulayan Ozan ve Sunucu, kendilerine kol kanat gerecek her şeyi bilen bir sultan arayan kuşlar, doğaya ve kendilerini yok sayan yöneticilere karşı mücadele veren Anadolu köylüsü, halkının karnını doyurmak için yola çımış bir kahramanken kendi anlam arayışına düşen Yunus, insanlara kainatın sırrını/görünenin arkasındaki görünmeyeni göstermek için çabalayan dervişler, halkı düşünmeksizin kendi çıarları için savaşı, yıkımı ve ihaneti tercih eden sultanlar, komutanlar, vezirler oyun boyunca her biri biriyle bağlantılı olmakla beraber diğer yandan her birinin hikayesi ayrı bir düzlemde kendini gösterir.

Köy seyirlik oyunlarının yapısına ve içeriğine dair sıralanabilecek; oyunun doğal ortamda boş bir alanda oynanması, seyirci ile içiçeliği, soyutlama ve yabancılaştırma estetiğine dayanması, müzik ve dans kullanımı, kostümün ve dekorun sıradanlaştırılması ve basitleştirilmesi, oyunun içinde ritüel oyunların yer alması, çatışma motifinin (ak-kara ölüp-dirilme, bolluk-bereket karşıtllğı) işlenmesi gibi unsurları, Yunus Diye Göründüm'de de tespit etmek mümkündür.

\section{Oyun İçinde Oyun}

Köy seyirlik oyunlarının yapısına hem içerik hem de biçim bakımından benzerlik gösteren ve oyunda tiyatrosallığı sağlayan en önemli etmen oyun içinde oyun yapısıdır. Bu tür yapılarda oyunun bir oyun, oyuncunun bir oyuncu olduğu; oyuncuların da seyircinin farkında olduğu özellikle vurgulanmak üzere hareket edilir. Oyun içinde oyun kurgusuna Açı Biçim-göstermeci tiyatronun sıklıkla başvurduğu görülmektedir; köy seyirlik oyunlarının da en ayırıcı özelliklerinden birini oluşturmaktadır. Çünkü köy seyirlik oyunları, köylünün "oyun yapma, oyun çıkartma" geleneğinin bir parçasıdır ve oyun içinde oyun, oyunlarda kendini sıklıkla gösteren bir motiftir (Tekerek, 2008, s.122). Bir oyunda oyun içinde oyun kurgusunun varlığından bahsedebilmek için Erkek (1999) çalışmasında “oyun içinde kimliği belirlenmiş en az bir oyun kişisinin kendi kimliği dişında bir kimliğe, kılı̆̆a bürünmesi, ikincisi; en az bir oyun kişisinin oyun içinde seyirci konumuna düşmesi, üçüncüsü; sahne oyunu içinde yer alan bazı sahnelerin ayrı bir yapı ve üslup taşıması; dördüncüsü ise; sahne oyunu içinde kuralları ve yapısı farkl, bütünlüklü bir oyuna yer verilmesi” (s.3) özelliklerini sıralar. Sıralanan özelliklerden en az birini taşıyan oyun için, oyun içinde oyun kurgusundan bahsetmek mümkün olur. Oyun içinde oyun kurgusu farklı biçimlerde kendini gösterebilmektedir; Yunus Diye Göründüm'de bütün oyunun 'oyun içinde oyun' olarak sergilendiği oyunlar kategorisinde değerlendirmek mümkündür. Bu yapı iki katman şeklindedir: Ozan ve Sunucu'nun varlığı dış oyun olarak birinci katmanı; Yunus Emre'nin menkıbevi hayatı odağında sergilenenler ise iç oyun olarak ikinci katmanı oluşturur. Bir oyunun içinde yer aldıklarını anlatıcı olarak seyirciye dönük söylemleri ile hissettirmeleri oyunun başından itibaren seyircilerin bir oyun izlediklerini asla unutmamalarını sağlarlar. Ozan ve Sunucu kendi aralarında tartıştıkları konunun gösterimini ise seyirciye iç oyunda sunarlar. Sadece sunmakla da kalmaz kimi zaman olayları anlatır ya da özetler kimi zaman da iç oyuna dahil olup bir rol üstlenirler. Burada anlatıcı çoğunlukla Ozan olurken Sunucu ise iç oyunda rol alan oyun kişisidir.

OZAN - Canım ne demek olacak, bu sahnede Haberci'yi sen oyna demek isterim.

SUNUCU - (Bir an bocalar, sonra omuz silkerek) Eh, oynayalım bakalım. (Haberci pozuna geçerek vitrinlere doğru koşturup Pervane’nin önünde bir dizini yere koyarak onu selamlarken efekt hafifler)

SUNUCU (HABERCİ) - Pervane efendimize haber vardır, gavga meydanından gelmiştir.

PERVANE - (Haberci'ye bakmadan) Aşikâr eyle haberi. (Asyall, 2010, s.192-193)

Böylelikle Ozan da Sunucu da bir oyunun içinde yer alan oyuncular olarak kabul edilmelidir. Oyun içinde oyun kapsamında değerlendirilebilecek bir uygulama olan oyun içindeki taklitlere ve kılık değiştirmelere örnek olarak görülen Ozan'ın ve Sunucu'nun iç oyundaki kişilerle girdikleri iletişim, iç oyunda üstlendikleri rol tek örnek değildir. Oyunun tamamında bazı oyun kişilerinin tek bir kimliğe ve kişiliğe sahip olmadıkları, birden fazla role büründükleri görülür. Bu durum tiyatro metnin başında yazar tarafından özellikle belirtilmiştir. "Not: 
Hüthüt, Hacı Bektaş-ı Veli ve Taptuk Emre rollerini aynı oyuncu oynayacaktır. Yine Kuşlar, Köylüler ve Erenler ile Bacılar da ayn oyuncu grupları tarafından oynanacaktır." (Asyalı,2010, s.120). Oyunda kullanılacak giysiler de bu bakımdan değerlendirilir ve bunun amacını yazar "hem dramatik çizginin bütünlüğünü ve birlikte gelişimini sağlamak hem de öz düşüncenin anlatımını çağrışımlar yoluyla zenginleştirmek” sözleriyle açılar. Kılık değiştirmeler oyun boyunca devam eder ve kılık değiştirme ve başka bir role bürünme sahnede birdenbire gerçekleşir. Bir oyuncunun birden fazla rolü yansılaması, kılık değiştirmenin sahnede gerçekleşmesi seyircinin seyrettiği oyunla özdeşleşmesini engelleyen ve yapılanın bir oyun olduğunu anımsatan unsurlar olarak da önemlidir. Bu duruma bir diğer örnek oyundaki dans ve müzik kullanımıdır. Özellikle sahne değişimlerinde olmak üzere oyunun başından sonuna kadar ağırlığının hissedildiği sözlü ve sözsüz müzikler, halkın ritüel dansları, Erenlerin ve Bacıların dansları, Yunus Emre'nin sesinden dinlenen dörtlükler, Kuşların şarkıları ve dansları ile yine oyun kesintiye uğratılarak seyredilenin bir oyun olduğu gerçeğinin seyirciye daima hatırlatılması söz konusudur. Anadolu köylüsünün sergilediği oyunlarda ve törenlerde türkü ve danslar, dualar, mani ve tekerlemeler sıklıkla kullanılan motiflerdir, oyunlarda ve törenlerde topluca yapılan danslar bolluk ve bereket, iyinin kötüye galibiyeti, eskinin gidişi ve yeninin karşılanması için büyüsel bir motif olduğu gibi topluca öğesi ögesi olarak işlevsel bir kullanıma sahiptir (Tekerek, 2008, s.124). Asyalı’nın oyununda da dans ve müzik kullanımını işlevseldir; bir yandan ritüel oyunlarda büyüsel bir motif olarak varlık göstermeleri diğer yandan anlamı güçlendirmek üzere kullanılmaları söz konusudur.

\section{Çatışma veKarşıtlıklar}

Köy seyirlik oyunlarında anlamsal açıdan önemli bir yer tutan ak-kara, eski-yeni, iyi-kötü, ölüp dirilme gibi karşıtlıkları barındıran temel çatışma motifinin oyunun odak noktasını oluşturmak üzere Yunus Diye Göründüm'de de kullanıldığı görülür. Oyunda farklı şekillerde gerçeğin sorgulanması bu bağlamda değerlendirilebilecek ilk veridir. Görünür olan ve görünürün ötesinde gizli kalanın ikiliğini/çatışmasını oyunun başından sonuna kadar izleyici hemen her sahnede takip eder. Oyunun bir anlamda yöneticisi konumunda sayılabilecek anlatıcıları Ozan ve Sunucu, oyunun temelindeki karşıtllğı kendi üstlerinde toplarlar. Burada Sunucu resmi tarihi önemser ve savunurken Ozan ise halkın yaşantısına, başından geçenlere bakmak gerektiğini düşünerek rütbeyi, makam ve mevkiyi önemsemez; insanı önemser.

Sunucu- (Omuz silkip, dudak bükerek, alaylı konuşur) Tarih dediğin bu mudur? Bunların hepsi masal.

Ozan- Masal buysa gerçek nedir?,

Sunucu- Gerçek kitapta yazılı (Kasılarak ve tumturaklı, abartılı vurgularla) O vezirler, o sultanlar, o kahraman komutanlar...Tarihi yaratan onlar.. (Asyalı, 2010, s.134)

Ozan ve Sunucu'nun tarihi gerçekler konusunda "gerçek tarih kitaplarda yazan mı yoksa adı, yaşadıkları anılmayan halkın yaşamı mı" sorusundan hareketle başlattıkları tartışma, bir karşıtlık düzleminde oyunun her sahnesinde farklı olaylar ve biçimlerde kendini tekrar eder. Feridüddin-i Attar'ın Mantıku't-Tayr eserinin kısa biçimde yeniden yazımı sayılabilecek Hüthüt ve kuşların varlığı, oyundaki görünenin ötesinde başka bir gerçeğin olduğu bilgisini desteklemektedir. Kuşlar da bu bağlamda bir yansılama olarak görülebilir.

KUŞLAR (Dansı sürdürürken şarkı yükselir. Hüthüt’ün çevresinde dans ederek, şarkıyı söylerler)

"Her ülkede var bir sultan,

/Kande bizim sultanımız?/

Yeden-güden olmaz ise/

Bozulurmuş dirlik düzen

(...)

KUŞLAR (Dans ederek çıkarken)

Öylesine bir sultan ki

Kul olalım kendisine

Üstümüze kanat gersin

Derman olsun derdimize (Asyal, 2010, s.123). 
Mutlaka kendinden başka birinde doğruyu, aklı arama söz konusudur burada. Kendilerine bir sultan arayan kuşlar, kendilerinden daha fazlasını bilen, kendilerine yol gösterecek başka bir akla ihtiyaç duyarlar. Halbuki sonuçta ulaştıkları gerçek, o akla kendilerinin sahip olduğu; aradıkları sultanın ise kendileri olduğudur. Tarihte yaşanan olaylar için de bu durum geçerlidir. Tarih kitaplarında anlatılanlar, tek düze ve tek bir bakış açısına sahiptir ve sonuçlanmış olaylardır. Resmi tarih kayıtlarında sonuca giden yolda yaşananları, insan gerçeğini görmek mümkündür değildir. Fakat olaylar bir tiyatro sahnesinde canlandığında atılan adımların, verilen kararların arka planını görmek mümkün olabilir. Bu oyunda taht savaşları esnasında verilen her kararın arkasında gizlenmiş/görünmeyen başka bir hareket/düşünce/plan ile karşılaşlır. Yöneticilerin kendi arasında da halka karşı da daima gizli emelleri bulunmaktadır. Yunus'un kişisel deneyimi de görünen/görünmeyen ikiliğini içinde barındırmaktadır. Yunus, köyüne buğday getirmek üzere yola çımışken yolculuğu başka bir yere evrilir. Hacı Bektaş-1 Veli'nin yönlendirmesiyle yolculuğunun seyri ve amacı değişen Yunus'un bu yolculuk içinde de kimi zaman göz önündeki gerçeğe saplanıp kaldığı olsa da yolculuğunun sonunda görünenin ötesindeki anlama ulaştı̆̆ı görülür.

En nihayetinde tüm durumlar için varılabilecek sonuç ise her ne arasan kendinde araman gerektiği düşüncesidir. Sevgi de akıl da direniş de insanın özünde yer almaktadır ve bu gerçeğe ulaşabilmek için apaçık göz önünde bulunan bilgiden daha fazlasına ihtiyaç duyulmaktadır. Oyundaki 'bilmek uğruna ölmek gerektiği’ vurgusu pes etmeden anlam arayışının peşinden gitmek gerekliliğine işaret eder. O halde koşullar ne olursa olsun insan direnecek ve doğruya ulaşmak için pes etmeyecektir. Yazarın da eserleri ile ilgili vurguladığı nokta tam olarak budur.

Oyunun temel düşüncesini oluşturan bu fikri destekleyecek bir diğer çatışma ise yöneten-yönetilenler çatışmasıdır. Halkın, yöneticiler tarafından sömürülmesi, bir savaş aleti olarak kullanılması ve bir insan olarak asla önemsenmemesi oyunda iyi kötü karşıtlığını açı̆̆a çıkaran en somut göstergedir. Aynı zamanda yazarın epik tiyatrodan hareketle takındığı eleştirel ve politik tavrı da bu sayede görmek mümkündür. Aç kalan, susuzluk ve kuraklık ile mücadele eden halkın zor koşullarda eline geçecek bir avuç buğdayı Bey'in, Sultan'a göndereceği askerleri beslemek üzere köylünün elinden zorla almak istemesi; Sultan'ın hükümdarlığını sürdürebilmesi, daha fazla toprak sahibi olması için onun adına savaşa gidecek askere ihtiyaç duyduğunda köylülerin arasından asker toplamaya çalışması ve kendi çıkarı için halkın canını savaşlarda feda etmesi gibi durumlar yazarın ortaya koyduğu eleştirel tutuma işaret etmektedir. Bunu da sadece sahnede göstermekle yetinmeyerek Sunucu'nun ve Ozan'ın da tartışma konusu yaparak Ozan'ın durumu tüm açılı̆̆ı̆la değerlendirmesi ile seyirciyi düşünmeye ve izledikleri karşısında eleştirel bir tutum takınmaya sevk ettiği söylenebilir.

Anadolu'da oynanan köy seyirlik oyunlarında çatışmanın sonunda iyinin kötüye galip gelmesi eskinin kovulduğu yeninin bolluk ve bereketi getirdiği görülür. Yunus Diye Göründüm için de çatışmanın insan lehine sonuçlandığı söylenebilir. Halkın iyiliğini düşünmeyen ona eziyet eden yöneticilerin çok güçlü olmalarına rağmen ölmelerine karşılık "Eğer insan isen ölmezsin, korkma" başlığını taşıyan "Son Oyun"da Yunus Emre'nin varlığı bir güç olarak ortaya çıkar. Yöneticilerin hırsları ve çıkarları uğruna, kendilerini savaşın ortasında bulan Anadolu halkının savaş meydanında suçsuzca katledilmesinin ardından oyunun sonunda, Yunus Emre'nin şiirini okuması ve bir taraftan da "çarh urup dönmeye başlaması"nı izleyen zamanda halkın birer birer ayağa kalktığı yani dirildiği görülür. Anadolu köylüsünün galip geldiği bu çatışmada köylünün ve Türkçenin, Türk kültürünün sesi olan Yunus Emre, insan sevgisine ve hoşgörüye dayanan felsefesi ile, önemli bir sembol olarak kullanmıştır. Seyircinin oyun boyunca -Ozan ve Sunucu aracılığıyla- tarihi gerçekleri sorgulaması, insanın olaylar ve durumlar karşısındaki tavrını, gelişimini gözlemleyerek irdelemesi sağlanmış olur. 


\section{Ritüelin Görünüşü}

Köy seyirlik oyunlarının en önemli ögelerinden dans ve müzik Yunus Diye Göründüm'de en fazla faydalanılan motiflerden biri olarak izleyicinin karşısına çıkar. "Kuşların Özlem Şarkısı" ve "Kuşların Özlem Dansı" kuşların kendi hikâyelerini pekiştirirken hem de oyunun genel iletisini destekler niteliktedir. Sahne geçişlerinde de özellikle kuşların şarkıları ve dansları önemli bir yer tutmaktadır. Kuşların dışında bir diğer önemli dans ve müzik kullanımı köylülerce ve Taptuk Emre dergâhında erenlerce gerçekleştirilir. Köy seyirlik oyunlarında önemli bir yere sahip olan bazı ritüellerin bu oyunda da kullanıldığını söylemek mümkündür. Köylünün sevincini de üzüntüsünü de dile getirmek için dansa ve müziğe başvurması kendini farklı şekillerde gösterir. Oyunun birinci sahnesinde İbiş Ana’nın kurak toprak karşısında toprağı çapalayarak güvercin dansı yapması ve Yunus'un da ona katılması; onuncu sahnesinde köylünün hasadı yansılayan bir dansla şenlik içinde olması ve İbiş Ana’nın “Güvercin Türküsünü” söyleyerek dansa katılması; tarladaki ekini istila eden çekirgelerin varlığının da danslı-müzikli çekirge oyunu ile yansılanması; on ikinci sahnede Yunus'un Taptuk Emre'nin dergahındaki varlığının, barındırdığg anlamın, dilinden düşen şiirlerin dans ve müzikle gösterilmesi oyunda karşılaşılan dans ve müzik kullanımının örnekleri olmasının yanında daha büyük bir anlama sahiptir. $\mathrm{Bu}$ anlam, oyunun içine yerleştirilmiş olan ritüel oyunlar olmaları dolayısıyladır. Nihat Asyalı'nın, oyununu kurgularken Anadolu köylüsünün ritüel oyunlarını dış çerçeve olarak kullanmak yerine oyunun içine motif olarak yerleştirdiği söylenebilir. Köylünün yılın belirli zamanlarında gerçekleştirdiği ritüeller bu oyunda Anadolu köylüsünün yaşamını gerçekçi ögelerle görmeyi sağlamaktadır. Oyunun tamamında çoğunlukla ritüel bir oyun olarak yer verilen dansın ve müziğin kullanımının bu oyunun en ayırıcı özelliklerinden biri olduğu gerçeğini Ayşegül Yüksel'in tespitiyle desteklemek mümkündür:

Anadolu'nun çeşitli ritüellerinden yola çıkılarak yaratılan çeşitlilik yoluyla çağdaş Türk Tiyatrosu'nda zengin bir yeni biçem oluştuğu söylenebilir. Bu biçemin 'söz' den çok şarkıya, dansa ve bedensel anlatıma dayalı olması, popüler halk tiyatrosu geleneğinin 'söz’ ağırlıklı olma sakıncasını ortadan kaldırmakta, kültürel kimliğin, 'sözsüz' göstergeler yoluyla çok daha evrensel çağrışım alanları oluşturmasını olanaklı kılmaktadır (1999, s.323).

Nihat Asyalı oyunun içine yerleştirdiği en önemli unsurlardan biri olan ritüel oyunların değerini, dans ve müzik konusunda oyunun başında belirttiği not ile de desteklemektedir: "Müziğin ana Tem’i Hacı Bektaş-ı Velinin 'insan isen ölmezsin korkma' dizesindeki bildiri olmalıdır (ki oyunun bildirisi de budur). Bu nedenle, Alevi-Bektaşi nefeslerinden yararlanılabilir. Danslar için de ayn şeyler düşünülmüştür. Danslar da semah üstüne kurulabilir" (2010, s.121). Oyunda Yunus Emre kadar Hacı Bektaş Veli’nin de öğretisi ve varlığı ayrıcalıklı bir yer tutmaktadır. Yazar oyununa sadece Alevi-Bektaşi nefeslerini ve semahı yerleştirmekle kalmamış aynı zamanda Türk kültüründe menkıbelerde, masallarda, efsanelerde sıklıkla görülen don değiştirme motifini de kullanmıştır. İnsan, hayvan ya da nesneye dönüşme şeklinde gerçekleşen don değiştirme bu oyunda hayvana ve insana dönüşme şeklinde kendini göstermektedir. Hayvan kılığına girme ya da hayvanı yansılama motifi, köy seyirlik oyunlarının içinde de önemli bir yer tutmaktadır. Oyunda özellikle güvercinin vurgulanması dikkate değerdir çünkü güvercin, Anadolu'da Hacı Bektaş Veli ile özdeşleşen bir kuş olarak kabul görmektedir. Üstelik anlamsal olarak da oyunun iletisini desteklemektedir: "Ermişlerin ya da şamanların kuş donuna bürünmesi Tanri’ya yakın olan ve kutsal sayılan, üstün tutulan kimselerin bir kerameti, meziyeti olarak algılanmakta ve bu kimselerin Tanrı ile bağını vurgulamak iç.in "güvercin" tercih edilmektedir. Çünkü barışın ve sükunetin sembolü olarak güvercin don değisstirme motifinin en önemli vasıtasıdır" (Küçük, 2020, s.108). Bunun yanında oyun boyunca insandan hayvana hayvandan insana doğru olan değişim ritüel kökenli oyunlara önemli bir gönderme olarak okunmalıdır. 


\section{Sonuç}

Nihat Asyalı'nın Yunus Diye Göründüm'de, her ne kadar Yunus Emre'nin menkıbevi hayatını ele almış olsa da, amacının Yunus Emre'nin hayatını yeniden anlatmak olmadığı açıktır. Hem Türk tiyatrosunun kaynaklarından beslenerek modern bir metin kaleme almak hem de Yunus Emre'nin kişisel hayatıyla da yaşadığı devrin tarihi gerçekleriyle de bağ kurarak insanın değerini tartışmak ve yaşadığı zorluklar karşısında göstermesi gereken dirence işaret etmek yazarın temel amaçları olarak okunabilir. Asyalı oyununu açık biçimgöstermeci tiyatro olarak kurgulamış ve bu bağlamda bir taraftan epik tiyatronun hem biçeminden hem de toplumsal ve politik konuları ele alan eleştirel-gerçekçi tavrından faydalanırken diğer taraftan geleneksel Türk tiyatrosunun içinde önemli bir yapı olan köy seyirlik oyunlarının zengin anlamsal ve biçimsel yapısına yaslanmıştır. Yunus Emre'nin hakikati arama yolculuğu oyunda farklı grupların arayışlarıyla kesişir ve oyunda insanın gerçeği arama ve bulma serüveninde koşullar ne denli değişirse değişsin -daima kendine döndüğüvurgulanır. Yunus Emre'nin yolculuğuna eşlik eden kendi içlerinde bir arayış sürecini yaşayan kuşlar da oyunun iletisini desteklemektedir. Simurgu arayan kuşların yolculuğu ile Yunus'un yolculuğu paralellik göstermektedir çünkü her iki taraf da asıl değerin kendisinde olduğunun bilincinde değildir. Zorlu bir yolculuk yapar, sınanır ve sonunda gerçeğe kavuşurlar. Oyunun eleştirel-gerçekçi tavrının görüldüğü kısım ise Anadolu köylüsünün hem zor doğa koşulları karşısında hem de kendi menfaatlerini düşünmekten başka hiçbir şey yapmayan yöneticilerin karşısındaki çaresizlikleridir. Ezen-ezilen ilişkisinin tarihi gerçeklerin ne olduğu sorgusuyla ilişkilendirilmesi yazarın özgün buluşlarından biridir.

Yunus Diye Göründüm'de kllı değiştirmenin sahnede gerçekleşmesi, bir oyuncunun birden fazla role bürünmesi, sahnedeki dekorun göstermelik, gelişigüzel kullanılması; oyunun kurgusunda bunun bir oyun olduğunu gösterecek yapının (oyun içinde oyun) kullanılması ve içinde çatışmayı barındırması -ki bu yöneten yönetilen çatışması olarak kendini gösterdiği gibi ozan ve sunucu arasında da tarihin anlamlandırılması konusunda tarihin kitaptaki savaşlardan $\mathrm{m} ı$ halkın yaşantısından $\mathrm{m}$ ibaret olduğu çatışması ile de kendini göstermektedir- gelenekselin ve modernin kesişim noktasında yer alan oyunun biçimsel ve anlamsal yapısını oluşturan önemli unsurlardır. Eserin temelinde yer alan ve başından sonuna kadar işlenen çatışma, insanın kendini arama yolculuğu ile ilişkilidir. Yunus'un hayatında, kuşların kendilerine sultan arayışlarında, halk ve yöneticiler arasında daima görünen ve görünmeyen gerçeklerin yarattığ 1 çatışma yatmaktadır. İnsanın evrensel değerlerine dair kaleme aldığı bu oyunda yazar, gelenekseli ve moderni buluşturmakla savunduğu fikri, estetik düzeyde ortaya çıkarabileceği özgünlüğ̈̈ yakalamış ve aynı zamanda köy seyirlik oyunlarının tiyatronun zengin bir kaynak olarak yeniden doğuşuna sağlayacağı katkının değerini de bir kez daha açığa çıkarmıştır.

\section{Kaynakça}

Aktulum, K. (2013). Folklor ve metinlerarasılık. İstanbul: Çizgi Yayınevi.

Akyüz, M. (2017). Karşılaştırmalı edebiyat açısından Necip Fazıl'ın Yunus Emre tiyatrosu ile Nihat Asyalı'nın Yunus Diye Göründüm tiyatrosunun incelenmesi. Ana Dili Eğitimi Dergisi, 5(4), 880-887. doi: https://doi.org/10.16916/aded.339859

And, M. (1983). Türk tiyatrosunun evreleri. Ankara: Turhan Kitabevi.

And, M. (1985). Geleneksel Türk tiyatrosu -köylü ve halk tiyatrosu gelenekleri. İstanbul: İnkılap Kitabevi.

And, M. (2012). Oyun ve bügü -Türk kültüründe oyun kavrami-. İstanbul: YKY.

Asyalı, N. (2010). Toplu oyunları I- Direniş Üçlemesi: Ateşle Oynayan/Rab Şeytan'a Dedi ki/Yunus Diye Göründüm. İstanbul: Mitos Boyut.

Aşkın, F. (2011). Çağdaş Türk tiyatrosunda Yûnus Emre (Yayımlanmamış yüksek lisans tezi). Dumlupınar Üniversitesi, Kütahya. 
Ayvazoğlu, B. (2014) Yunus, ne hoş demişsin Cumhuriyet sonrası Yunus Emre yorumları. İstanbul: Kapı Yayınları.

Çalışlar, A. (2004). Tiyatro kavramları sözlüğü. İstanbul: Mitos Boyut Yayınları.

Çınar, E. (2020).1980-2000 arası Türk tiyatrosunda biyografik oyunlar. (Yayımlanmamış yüksek lisans tezi). Hacettepe Üniversitesi, Ankara.

Doğan, A. (2009). Türk tiyatrosunda Brecht etkisi. Turkish Studies, 4(1), 409-422. Erişim adresi: http://turkoloji.cu.edu.tr/YENI\%20TURK\%20EDEBIYATI/abide_dogan_turk_tiyatrosunda_brecht_et kisi.pdf

Elçin, Ş. (1991). Anadolu köy orta oyunları (köy tiyatrosu). Ankara: Türk Kültürünü Araştırma Enstitüsü.

Erkek, H. (1999). Oyun içinde oyun. Ankara: Kültür Bakanlığı Yayınları.

Günay, U. (1990). Türk kültürü açısından Yunus Emre. Türk Halk Kültürü Araştırmaları (Yunus Emre Özel Sayısı), 1, 33-50. Erişim adresi: http://turkoloji.cu.edu.tr/GENEL/gunay.pdf

Karadağ, N. (1978). Köy seyirlik oyunları. Ankara: Türkiye İş Bankası Yayınları.

Korkmaz, G. (2019). Türk Tiyatrosunun postmodern poetikası I: köy seyirlik oyunları. İstanbul: Mitos Boyut.

Küçük, M. A. (2020). Orta Asya'dan Anadolu'ya Türk geleneğinde 'don değiştirme'. bilig - Türk Dünyası Sosyal Bilimler Dergisi, 94, 97-122. doi: https://doi.org/10.12995/bilig.9405

Metin Basat, E. (2017). Köy seyirlik oyunlarında insan, doğa ve topluluk ilişkisi. Ankara: Grafiker Yayınları.

Özdinçer, F. (2011). Anadolu köy seyirlik oyunlarının gösteri danslarına dönüştürülmesinde yöntem önerisi ve bir uygulama örneği. (Yayımlanmamış doktora tezi). Dokuz Eylül Üniversitesi, İzmir.

Şengül, A. (2020). Sahnedeki mistik/derviş: tiyatro diliyle Yunus Emre. Tarihten Sahneye Türk Tiyatrosu Üzerine Araştırmalar (s.337-347) içinde. İstanbul: Kesit Yayınları.

Tan, N. (2001/4). Türk oyun yazarlarının Türk halk edebiyatından yararlanarak yazdıkları oyunlar. folklor/edebiyat, $\operatorname{VII}(28), 121-125$.

Tan, N. (2001). Yunus Emre konusunda yazılmış oyunlar. Türk Dili, 589, 44-47.

Tangal, M.M. (2020). Köy seyirlik oyunlarının dramatik sahne metnine dönüştürülmesi ve yeni bir seyirlik oyun. (Yayımlanmamış yüksek lisans tezi). Ankara Üniversitesi, Ankara.

Tecer, A.K. (1940). Köylü temsilleri. Ankara: Çı̆̆ır Mecmuası Neşriyatı.

Tekerek, N. (2008). Köy seyirlik oyunları. İstanbul: Mitos Boyut.

Töre, E. (2009). Türk tiyatrosunun kaynakları. Turkish Studies, 4(I-II), 2181-2348. doi: http://dx.doi.org/10.7827/TurkishStudies.614

Ulutaş, N. (2018). Divane Ağaç (Yunus Emre) oyununda islam sonrası şamanist izler. Ahtamara Uluslararası Multidisipliner Çalışmalar Kongresi Tam Metin Kitabı (s. 428-436) içinde. Van: İKSAD Yayınevi.

Yüksel, A. (1999). Türk tiyatrosu'nda ulusal/uluslararası kimlik sorunu. Bilanço 1923- 1998: Türkiye Cumhuriyeti'nin 75 Yılına Toplu Bakış Uluslararası Kongresi Bildiriler Kitabı I (s. 323-330) içinde. İstanbul: Tarih Vakfi Yayınları. 


\section{Extended Abstract}

\section{Purpose}

The aim of this study is to reveal the manner of editing the author used in a theatre play in which Yunus Emre's life is the subject. The method of the editing process of the play, which contains traces of theatrical village plays, is investigated. This study tries to find answers to questions such as "How does the author benefit from both traditional Turkish theatre and contemporary theatre?", "How did the author approach Yunus Emre?", "How is it possible to evaluate the play?", "What did the author question in the play?", "How did the author create the text?", "To what extent does he benefit from music and Yunus' poems?". The importance of the questions sought to be answered in the research stems from the fact that it will reveal how a wealth of a culture is reproduced through a contemporary theatre play and thus continues to live in a modern world by transformance. This study is necessary as it will contribute to the field as an exemplary text analysis that will illuminate the issue of how theatrical village plays materialise in modern texts and how cultural continuity perseveres.

\section{Design and Methodology}

In this study, the form and content of a theatrical play, which is fictionalized by making use of the tradition of theatrical village plays and epic theatre will be examined. In the process of this research, the characteristics of theatrical village plays and epic theatre will be evaluated first. Then, the theatre play will be analysed in the context of these features. The features that are to be investigated in the text of the theatre are features of theatrical village plays.

Contemporary theatrical village plays written as dramatic texts are plays that reflect the essence and form of traditional theatrical village plays and are written with contemporary play techniques from an aesthetic point of view. These games are written to be watched by a ticketed audience, staged by a director and played by professional actors, in the theatre hall or another venue suitable for theatrical plays. Contemporary versions of theatrical village plays, unlike the traditional versions, achieve a dramatic text structure by being fictionalized with drama techniques and a social subject and theme, considering cause and effect, at the level of entry and development, with typical and dimensional characters. Reflecting the structural features of open form exhibition drama, embedded narratives, and the aesthetics of abstraction and alienation form the basis of these plays.

\section{Findings}

It is seen that Yunus Emre's legendary life manifests itself in this play as in other works, but the aim is not to retell Yunus Emre's life. Yunus Emre's journey of seeking the truth intersects with the search of different groups in the play, and it becomes clear that the aim of the play is to tell the truth that man always returns to himself, no matter how much the circumstances change in his adventure of seeking and finding the truth.

When the play is examined, it is seen that it has traces of the theatrical village plays in the following respects: the change of costume takes place on the stage, an actor takes on more than one role, the decor on the stage is used for show and is used haphazardly. The use of the structure that contains the conflict of black and white, which manifests itself as the conflict of the ruled and the ruler, as well as the conflict between the poet and the presenter in the meaning of history, whether the history consists of the wars in the book or the life of the people in the play, shows that this is a rendering in the fiction of the play as the embedded narrative.

This conflict is related to the human journey of self-discovery. It is seen that the conflict is reflected throughout the play. In Yunus' life, there is always the conflict between the people and the rulers, created by the visible and 
invisible realities, in the birds' search for sultans. In this play, which he wrote about the universal values of man, the author has achieved the originality that he can reveal at the aesthetic level by bringing the traditional and the modern together.

\section{Research Limitations}

This theatre play should not be seen as just a dramatic theatrical village play.

\section{Implications (Theoretical, Practical and Social)}

Yunus Emre is one of the most prominent figures of Turkish culture, language and literature. Due to his works and life, his language awareness, the values he believes in/ stands by, his thoughts/ teachings create a great influence area after his age as well as in his own age. In addition to the academic studies carried out on Yunus Emre, it is possible to talk about the existence of artists who were influenced by, nourished by, and commemorated Yunus Emre in the world of art and especially in the literary environment, revealing new ideas and form experiments. In this context, in different periods of modern Turkish literature, artists who wrote different types of works with different perceptions and thoughts, sometimes made explicit and sometimes implicit references to Yunus Emre, and sometimes they wrote modern works in which they rewrote his life. Especially in modern Turkish theatre, there are many works about Yunus Emre. So far, mostly general evaluations have been made on other works written about Yunus Emre. This study has shown that reading the works created by Yunus Emre's rich associative world with different methods will make a great contribution to the field. In addition, it is an important issue that traditional Turkish theatre is a source that feeds modern texts in theatre research. The determination of the traditional effect in modern theatre plays will also make important contributions to the field.

\section{Originality/Value}

Although there have been important studies on the reflections of theatrical village plays in contemporary theatre texts, there is no previous study on this theatrical play of Nihat Asyalı in this context. The original fiction of the play, which emerged with the intersection of the traditional and the modern, is discussed for the first time in this study. In this context, the study also contains important data for the history of modern Turkish theatre.

Araştırmacı Katkısı: Nurtaç ERGÜN ATBAŞI (\%100). 